\title{
Model and Orientation of Economic Development During Covid-19 Pandemic: Case Study of MSMEs in Indonesia
}

\author{
Apridar $^{1 *}$, Rita Meutia ${ }^{1}$ \\ Lecturers in Economics and Business Faculty, Universitas Malikussaleh \\ Corresponding Author: apridar@unimal.ac.id
}

\begin{abstract}
Pandemic virus corona not just a virus known as Covid-19 has caused turmoil in the economic sector. Not only large industries, the corona virus pandemic has made MSME players in Indonesia nervous. Especially recently, a study said that if Covid-19 occurs in a long period of time, it will make Indonesia experience a decrease in the percentage of economic growth by $0.1 \%$ in Indonesia. 2020. There are real impacts that will be received, especially by the MSME sector in Indonesia. If we don't look for a solution to the problems that occur, the Covid-19 pandemic outbreak will be the blow of a tremendous wave of poverty against this nation. UMKM which dominates the nation's economic actors up to 91 percent is the largest portion that contributes to the welfare of the community. It can also be said, if MSMEs collapse, it will be the same as the destruction of Indonesian society. So that serious attention to saving MSMEs is a must. By using Google Trends analysis, we can find a suitable model of economic development future outbreaks covid-19 is the concept of economies oriented to the development of SMEs to economic development to businesses that use labor-intensive. The results of this study indicate that the empowerment of MSMEs can increase economic growth. This research can be used as input for policy makers and economic activity actors to be able to survive and the economy to remain stable during the Covid-19 pandemic in addition to being an additional reference for developing economic concepts to improve people's lives.
\end{abstract}

Keywords: economic development, productive economy, community empowerment, MSMEs

\section{INTRODUCTION}

The Covid-19 outbreak has spread so fast and has almost plundered throughout the world at least more than 210 countries have confirmed being infected with 120,568 people dead (tirto.id/14/4/2020). Super tiny viruses that can only be seen with an electron microscope have eaten away 99.7 percent of the Global Broto Domestic Product (GDP). Thus creating a market panic and world economic recession. This all-powerful recession beat various world recessions such as the 1997-1998 monetary crisis, the 2008-2009 European Union recession or the Russian crisis in 2015.
Economic problems that occur include an imbalance between production and consumption, the value of imports that are so far from exports, that economic growth has slowed down to even minus, resulting in skyrocketing inflation or deflation. These various problems will usually be followed by a high unemployment rate. With the occurrence of economic uncertainty, which also means a decline and economic downturn, so that investment that will absorb labor is getting nil due to uncertainty about profits for the company.

Table 1.

The IMF's 2020 Economic Growth Projection

\begin{tabular}{|c|c|cc|}
\hline 2019 & 2020 & Country \\
\hline 7 & 2.7 & Vietnamese \\
\hline 4.2 & 1.9 & India \\
\hline 6.1 & 1.2 & China \\
\hline
\end{tabular}




\begin{tabular}{|c|c|c|}
\hline 5.9 & 0.6 & Philippines \\
\hline 5 & 0.5 & Indonesia \\
\hline 2 & -1.2 & South Korea \\
\hline 4.3 & -1.7 & Malaysia \\
\hline 2.9 & -3 & World \\
\hline 0.7 & -3.5 & Singapore \\
\hline 0.7 & -5.2 & Japan \\
\hline 1.1 & -5.3 & Brazil \\
\hline 2.3 & -6.1 & United States of America \\
\hline 1.6 & -6.2 & Canada \\
\hline 1.4 & -6.5 & English \\
\hline 2.4 & -6.7 & Thailand \\
\hline 0.6 & -7 & German \\
\hline 1.3 & -7.2 & French \\
\hline 2 & -8 & Spanish \\
\hline 0.3 & -9.1 & Italy \\
\hline & & \\
\hline
\end{tabular}

Source: International Monetary Fund (IMF), April 14, 2020

MonitorData and the latest information Covid-19 in Indonesia on this Katadata microsite. The global economy is currently down due to corona virus pandemic. All sectors experienced contraction. The main cause is restrictions on human movement throughout the country to stop the spread of the covid-19 virus. The world monetary fund (IMF) in April called it worse than the great depression that occurred in 1930.

The market panic resulting from the covid19 outbreak is not an unreasonable reaction, where lives are at stake as a result of a virus that is invisible to the naked eye. Viruses that have been frowned 120 thousand over the lives of 1,7 million cases per 14 April 2020 the world is an outbreak that has devastated the world economy. Everyone is trying optimally to cope with the outbreak and trying to anticipate a weakened economy and some even negative so that development for the welfare of the community can recover.

Indonesia is targeting economic growth of 2,3 percent is a reasonable target if the pandemic period can be completed by the end of Mai 2020. This target will be difficult to achieve if the height of the pandemic that is unique to Indonesia shifted above the Mai Moon. In fact, it is not impossible that economic growth will be negative if the peak of the pandemic occurs at the end of 2020.

So it is not an exaggeration if the government tries hard so that the public is disciplined to limit physical distance and social activities (physical distance and social distance) and conduct self-isolation for migrants from outside the region and abroad so that the coronavirus pandemic can be cut off the chain of development. The longer we finish the outbreak, the heavier it will be to be able to repair an economy that has started to weaken in growth.

Indonesia, which adopts an open economy, will certainly have a significant effect on the rupiah exchange rate with a minus trade balance. One way to anticipate this is by encouraging a movement to love domestic products as a joint movement to support the nation's economy.

BI liquidity injections that have been carried out into banks in large amounts of up to 300 trillion rupiah since early 2020 through the purchase of SBN from the secondary market, provision of liquidity to banks through a term-repurchase agreement (repo) repurchase agreement mechanism, as well as a decrease in banking minimum reserve will be able to increase banking liquidity in real terms will be 
sufficient (Ferry Warjiyo 8/4/20). The same must be done by fiscal stimulus by the central and regional governments in the form of social programs, industrial incentives and economic recovery which will certainly be able to encourage public consumption, production and investment in the business world, both MSMEs and corporations. With this stimulus, the economic enthusiasm in the situation of the Covid-19 outbreak will continue as we hope.

The relaxation of the microprudential regulation issued by the Financial Services Authority (OJK) is expected to make it easier for banks to finance MSMEs and the business world in the context of economic recovery. Under conditions of tremendous pressure on the current economy, synergistic smart policies are needed so that business activities can run smoothly and banks themselves will be more flexible in channeling financing to the business world.

The Covid-19 outbreak, which has become a scourge for the world today, is the right moment to serve as a momentum to empower Micro, Small and Medium Enterprises (MSMEs ) in the field of halal food products we empower. It's time for our bodies to be filled only with good and nutritious food. It's time to stop consuming foods that damage the body and the development of the soul and personality. Maintaining health, as well as supporting the rise of MSMEs, is the right opportunity to build a more balanced economy.

Micro, Small and Medium Enterprises (MSMEs) engaged in the food sector, in particular, need to be given serious guidance by the governmen . Serious support is very important. Apart from working capital support, marketing guidance and support is very important. So that they are able to innovate and compete with products from outside. Based on the description above, the problems in this research are: 1) What is the right economic development model during the Covid-19 outbreak. 2) How is the orientation and direction of development actually applied in Indonesia's economic development 3) Can the empowerment of MSMEs increase economic growth?

\section{LITERATURE REVIEW}

Micro, small, and medium enterprises ( UMKM ) is a general term in the realm of economics which refers

to productive economic enterprises owned by individuals or business entities in accordance with the criteria stipulated by Law No. 20 of 2008. Including the criteria for a micro business is a business that has a net worth of Rp. 50,000,000 , excluding buildings and land on which the business is located. Proceeds from sales of micro businesses each year of $\mathrm{Rp}$ $300,000,000$, - Small business is an economic business productive stand-alone, whether owned by individuals or groups and not as a business entity branch of a major company. Controlled and owned as well as being part of both directly and indirectly from medium-sized enterprises.

Meanwhile, medium-sized enterprises are businesses in a productive economy and are not a branch or subsidiary of a central company and are a direct or indirect part of a small or large business with their total net assets as regulated by statutory regulations. Medium-sized businesses are often categorized as a large business with the criteria of net worth owned business owners achieve more than Rp500,000,000 , - until Rp10,000,000,000, - and not including buildings and land where business. Its annual sales revenue reached $\mathrm{Rp} 2,5$ billion and $\mathrm{Rp} 50$ billion (Wikipedia)

Facing the Covid-19 Pandemic requires humility from all elements of society to hand over the handling of the Covid-19 pandemic to parties with relevant authorities such as WHO, Ministry of Health and the government (via the Covid-19 Prevention Task Force). Moreover, non-authoritative institutions must "know themselves" not to interfere with authoritative institutions and exacerbate the situation. There is a popular saying, if you can't help solve the problem then don't be a part of it.

Several previous studies by Dana Riksa Buana (2020) conducted research on the behavior displayed by people who did not comply with government calls based on cognitive bias. The research method used by this research is literature study with a descriptive analysis approach.

Adityo Susilo, et al (2020) In early 2020, the world was shocked by the outbreak of a new pneumonia that started in Wuhan, Hubei Province which then spread rapidly to more than 190 countries and territories. This outbreak was given the name of coronavirus disease in 2019 (COVID-19) caused by the Severe Acute Respiratory Syndrome Coronavirus -2 (SARS-CoV-2). The spread of this disease has had broad social and economic impacts

Fegi Merina (2020) b usiness online jember is any kind of online business activities p roduk $m$ urah a sli Jember are done online through internet network. Every business actor whose activities or all of his business is done via the internet, can say they are running an online business. Online business activities can include buying and selling activities online, as well as providing services online, and many other types of online businesses that we can find online in various 
fields, the point is if you have a business idea or fashion product you immediately start selling via the internet, a rtinya all the bus a just starting an online business.

Business activities online can be realized in various types (website, online shops, or marketplace, blog, social media accounts). where the benefits and and challenges of online businesses can increase the potential of online business is lucrative, but the process and the challenges that must be you face it is not something lightly There are many things that we can consider when starting an online business, especially if you are not someone who is familiar with computers, or has never even built a business before.

Some of the benefits that we can get include; hemat rent and employee costs, products are flexible, can be many kinds, ease of access via the Internet, anytime from anywhere, 24 hours 7 days a week. Even so, there are some challenges that inevitably we have to face, among others: m embutuhkan technical capabilities of the website and the internet, expense costs for gadgets, computers, and software support, risk online fraud and so forth. The knowledge on technology on how to use computers and supporting software, as well as how to use the Internet properly, will greatly assist us in conducting business online.

When the Covid-19 pandemic occurred, many people restricted from leaving the house, so the communication media via the internet grew rapidly. In fact, to buy goods especially basic needs, it is often done online. So that various online transactions grow so fast.

Based on literature review and several previous studies, the research framework can be described in Figure 1.

Based on the research framework above, the research hypothesis can be described as follows :

1) It is suspected that the economic development model that is oriented towards MSMEs during the
Covid-19 pandemic is very suitable for increasing the economic growth of the people.2) It is suspected that the economic development orientation is effective for economic growth in labor-intensive activities. 3) It is suspected that the empowerment of MSMEs can increase economic growth and reduce economic inequality in society.

\section{RESEARCH METHODOLOGY}

This research is qualitative descriptive. The research was conducted during the year 2020 in Indonesia by using primary and secondary data. Primary data is obtained from the results of field observations, namely by interviewing experts in the field of economics, especially those related to MSMEs and the online sales process. Interviews were conducted in person, telephone, FGD, internet interviews by email or other online tools. Secondary data were obtained from scientific journals and from a variety of sources, such as the Central Statistics Agency (BPS), the media a social and a 1 and other parties relevant. The sampling method for respondents used is based on non-probability sampling where the collection of information and knowledge from experts uses a purposive sampling method to determine which experts will be involved in the research. Purposive sampling method is a method of sampling that is performed based on the consideration of some suitable characteristics associated with members of samples needed to answer the research objectives. The considerations used to determine the expert are the suitability of expert education, expert experience expert position, and the most important track record of expertise is that the data is taken from respondents who master / are experts in the problem (Ascarya, 2005). The data obtained were analyzed by using analysis program Google Trend. Where the data questions were obtained and collected as well as in input in the data analysis program.

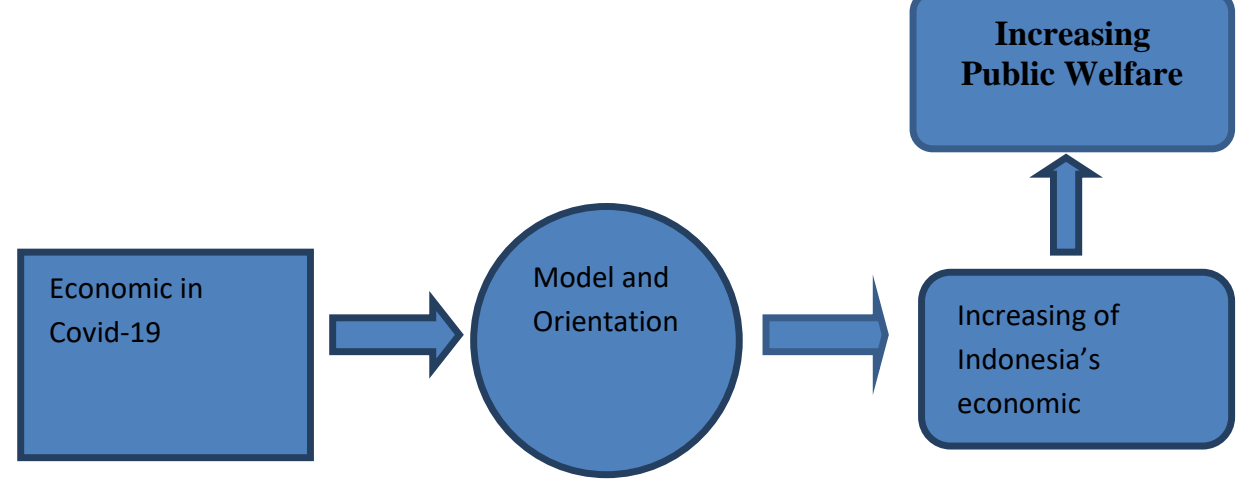

Figure 1.

Research Framework 


\section{RESEARCH RESULTS AND DISCUSSION}

Indonesia's economic growth in the first quarter of 2020 was recorded at 2.97 percent. It strayed far from the predictions of government is projecting economic growth at the level of 4 , 5 percent to 4.7 percent. This prediction is far different from the actual figures that have occurred. For the second quarter it was even crazier, namely economic growth to minus 3 to 5 percent, as stated by the Chairman of the Indonesian Chamber of Commerce and Industry Rosan Roeslani. The economic contraction, which is at 3 to 5 percent, is a situation where solutions and strategies must be found so that economic pressures do not get heavier.

Our figure in the second quarter is minus 3$5 \%$, because our economic growth is dominated by domestic consumption of around $57 \%$, investment of $32 \%$, government spending of $7-8 \%$ and the rest, exports and imports. Now it is domestic consumption that is disturbed. According to Rosan, disruption of consumption occurred in March in the last 2 weeks. However, this had a devastating impact on public consumption and caused the economy to decline.
Ber da sarkan number

Kemenaker (Kementeriran Employment) labor laid off or retrenched was approximately 2 million. But the figure we received from the association was 6 million, "said Chairman of the Indonesian Chamber of Commerce and Industry Rosan Roeslani in a virtual discussion, Saturday (16/5/2020).

Based on processed data from google trends, the results show that during the Covid-19 pandemic, MSMEs received a lot of assistance from the government, especially in carrying out various production activities. The government feels that to be able to generate economic activities that have decreased drastically, especially for the informal sector such as MSMEs, it is very necessary to encourage the assistance of business capital in particular. So that the government also changes policies, namely that village funds that have been disbursed to the community can be used to help MSME activities. This smart policy by the government has had a significant effect on the revival of community MSME activities .

Figure 2. Google Trends Data Processing Results

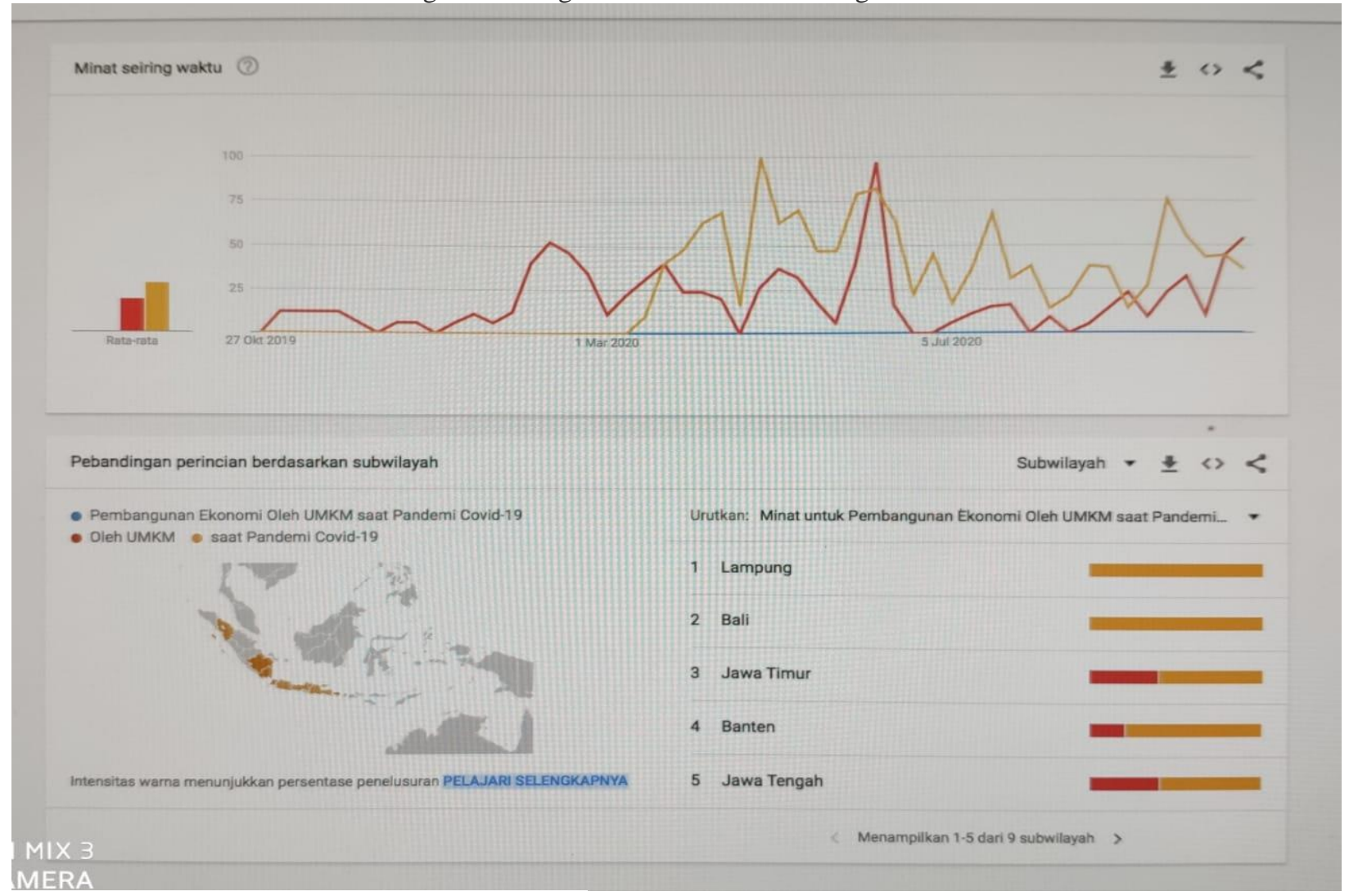

Source: Data processed with google trends (2020). 
From figure 2 the results if the data using google trends starting in March shows that the interest in the activities of SMEs began to rise sharply. The increase was mainly contributed to the UMKM BLT, online UMKM assistance, UMKM social assistance and others related to other UMKM. Comprehensive UMKM registration is the second position carried out by the community after assistance to MSMEs. The next thing that is also in the top five that has increased is the oneline UMKM and the UMKM problem as well as the business of the UMKM itself.

The national interest in developing MSMEs based on province has seen an extraordinary increase in the Lampung Province, which is then followed by the Province of Bali. For the third position is won by the Province of East Java, then for the fourth position is held by the Banten Province. For fifth place held by Central Java. From the data obtained, it illustrates that the areas where the development of MSMEs is increasing implies that the people of these areas prefer to rely on their economic activities to the creativity of a more independent society. The desire to become a civil servant as a community profession is decreasing. The awareness of opening a business independently even though it is small is more attractive to the community after the Covid-19 pandemic.

Based on these data, it is time to be used as a model for regional development with a more orientation towards business activities that create employment opportunities. Local governments in particular should pay more attention to MSMEs as business units to boost the people's economy. Guidance and preparation of business capital as well as protecting the distribution of spark plugs for MSME products must be the top priority of the government in maintaining the sustainability of the economy.

\subsection{The Future of the Indonesian Economy}

The impact of the Covid-19 outbreak on the world economy was also devastating. In the first quarter of 2020, economic growth in a number of Indonesia's trading partner countries grew negatively: Singapore -2.2, Hong Kong -8.9, the European Union 2.7 and China experienced a decline to minus 6.8. Several countries still grew positively but decreased compared to the previous quarter. United States fell from 2, 3 to 0.3, South Koreea from 2.3 to 1.3 and from 6.8 to 3.8 Vietnam. Indonesia experienced a deep contraction from 4.97 in the fourth quarter of 2019 to only 2.97 in the first quarter of 2020. The deep contraction in the 1st quarter in Indonesia was beyond estimation considering the physical distancing and PSBB arrangements came into effect in early April 2020.

Indonesian Economy Based on year-on-year growth, the largest source of economic growth in Indonesia in the first quarter of 2020 was in the information and communication sector at 0.53 percent. This is reasonable considering that with the advice not to leave the house, many people access jobs, entertainment and education through information technology. In line with this, the sales volume of PLN electricity to households has increased. Based on a release from the Central Statistics Agency, the number of foreign tourists coming to Indonesia in the first quarter of 2020 also dropped dramatically by only 2.61 million visits, a decrease of 34.9 percent compared to last year. This is in line with the prohibition on flights between countries which came into effect in mid-February. The number of rail and air passengers also grew negatively in line with the implementation of the PSBB. Then when will the Covid-19 outbreak end and how will it affect the Indonesian economy? (Kompas.com "Indonesia's Post-Pandemic Economy")

\subsection{The Impact of Covid-19 on the MSME Sector}

The Corona virus pandemic is not just a health disaster, the virus known as Cobid-19 has caused chaos in the economic sector. Not only large industries, the Corona virus pandemic has made SMEs in Indonesia nervous. Especially recently, a study said that Covid-19 would cause Indonesia to experience a decrease in the percentage of economic growth by $0.1 \%$ in 2020 . The data obtained actually decreased economic growth at a rate of minus 3 percent to 5 percent. Broadly speaking, here are the real impacts that Covid-19 has had on the SME sector in Indonesia.

\section{Decrease in Buying and Selling Activities}

Prompts social distancing in order to avoid transmission of the virus Corona wider, to some extent contributed to lower trading activity in the community.

For example, warteg entrepreneurs in Jakarta. According to the head of the Nusantara Warteg Community (Kowantara), Mukroni, the Corona virus has made the turnover of warteg entrepreneurs in Indonesia, especially Jabodetabek, decreased by 50 percent.

But fortunately, according to research conducted by the Center for Economic and Social Studies (CESS) and The Center for Micro and Small Enterprise Dynamic (CEMSED), SMEs in Indonesia are unique because they always have the ability to develop and survive during a crisis. 
This is evidenced by the initiative of warteg entrepreneurs who prefer to continue operating, but change their way of selling by only serving packaged purchases (to be taken home), not serving food purchases on the spot.

\section{Difficult to find raw materials}

The social distancing policy chosen by the Indonesian government has disrupted production activities. Some companies adopt a Work From Home policy, some decide to lay off their employees, to mass layoffs. According to the latest data from the Jakarta Manpower, Transmigration and Energy Office, as many as 30,137 workers reported having lost their jobs due to mass layoffs, while 132,2799 other workers lost their income because they were sent home without wages.

The domino effect of the hurricane of layoffs and laid off workers has sent production capacity into an extreme decline. Like it or not, this condition has led to scarcity of raw materials for home industry production, or to experience extreme price increases. For example, the SME sector for cake and bread makers is confused by the soaring prices of eggs and sugar. As a result, the selling price of the product was also increased. This choice is considered risky, considering that currently people's purchasing power is sluggish.

\section{Distribution is hampered}

The government continues to strive to maximize distribution channels throughout Indonesia through massive infrastructure development in Indonesia. The project has even been started since President Joko Widodo took office in his first term. The results are quite significant, the distribution channels are faster, the price gap can be cut, and the pace of the people's economy is getting faster.

$\mathrm{K}$ 's, Covid-19 had a 'crush' all that. According to data from the Indonesian Toll Road Association (ATI), the average daily traffic (LHR) of all toll roads in Indonesia has decreased between 40-60 percent since the beginning of March 2020. An extreme decline occurred in the Greater Jakarta area. If in February the number of passing vehicles reached 3.19 million vehicles, at the end of March, there was only 1.06 million left. This condition is expected to continue during the Corona virus pandemic.

The cessation of distribution activities is of course very detrimental to UKM business players. They are now confused about how to distribute their products, especially for SMEs that have begun to expand their market reach outside the region, or even across islands.

\section{Service Providers are Exposed to the Impact of Covid-19}

Not only SMEs engaged in the home production sector, those engaged in services also reported a significant decline in turnover. For example, barbers are forced to lose their income due to social distancing policies. Those who work as casual daily laborers, such as construction workers, makeup artists, wedding organizer workers, wedding photographers, and others are reportedly having difficulty earning income because a number of projects have to be postponed due to the Corona virus pandemic.

Luckily, the government is currently brave enough to take a policy by not imposing a lockdown, so that some SMEs in the regions still have the opportunity to find ways to 'survive'.

In addition, there are several other policies that are considered quite helpful for SME entrepreneurs, for example providing credit relaxation, eliminating electricity and discounts of up to 50 percent, as well as an easy capital injection program. This can be seen from the steps taken by the Financial Services Authority to issue a countercyclical policy as stated in ( press release No. HM.4.6 / 32 / SET.M.EKON.2.3 / 03/2020 by the Coordinating Ministry for Economic Affairs of the Republic of Indonesia ).

\subsection{The Importance of Information and Communication Technology for MSMEs}

Micro, Small and Medium Enterprises (MSMEs) are productive economic enterprises owned by individuals and business entities according to the criteria stipulated by law number 20 of 2008 . With this strategic position, MSMEs are the main pillars of supporting the Indonesian economy. More than 90 percent of the Indonesian economy is run by MSMEs, but the assets they own are less than ten percent of the total assets. This fact is one of the reasons why MSMEs have not been able to do much in their own country.

The Covid-19 pandemic situation is a momentum for every MSME to strengthen themselves to enter a field that uses a production process with qualified technology. Pandemic conditions have made everyone advisable to move by limiting physical contact. Many parties have started to limit themselves from making direct contact. In times of uncertainty, telecommunication services have seen an increase and have become an effective way of transactions during the current pandemic.

The government needs to provide full support for MSMEs to continue their activities with the support of digitalization towards the Global Market. The government needs to provide an optimal opportunity by way of setting up the infrastructure such as fiber optic digital technology throughout the 
village. 4200 BTM that must be built in 83 thousand more villages should be in the next year. This real support will make the empowerment of MSMEs even more real.

It is a necessity that cannot be negotiated anymore, namely all MSMEs to be connected to the Digital Market Place. This is a network that needs to be maintained so that they remain on the axis of the world economic arena. All UMKM in any field must be connected to the digital market place. The next task of the government is to provide institutional strengthening so that it can compete properly and properly. The disbursement of 124.6 million trillion funds for MSMEs in 2020 should be a part of continuous strengthening in strengthening the basic foundations of MSMEs. .

Creative work programs from various MSMEs such as traditional batik, various carvings of art are very important to be protected, such as by patenting their works of art. Synergy in building the nation's economy is needed. MSMEs engaged in any field need to have the same support in order to be able to run and develop. No matter how small the opportunity we get, it is very important for us to actualize it in a real product.

The common desire to develop the economy through MSMEs is a major force where there are 175 million or 65 percent of Indonesia's population engaged in MSMEs. This tremendous power is an unquestionable potential for developing the Indonesian economy. Whatever field that UMKM is engaged in, it needs support from the community. We need to create a common viewpoint in our joint commitment to build this beloved nation.

From various business sectors, the facts in the field show that only MSMEs have experienced positive growth. There are other sectors that have been minus in the second quarter of 2020. So it is not an exaggeration if the government must rely on MSMEs in building a better future economy. BPS data itself shows that Indonesian MSMEs are able to contribute 57 percent of the total Gross Domestic Product.

Still from BPS data, MSMEs in Indonesia also make the level of entrepreneurship increase every year. So that MSMEs become the main tools of our society in building an interpreter spirit. The instinct to read business opportunities is a special skill that must be trained to build a better national economy in the future. The attitude pattern in building the nation by increasing the number of interpreters is the right step in building a more prosperous nation in the future.

The opportunity to obtain financing for millions of micro and small customers needs an ecosystem that is synergized with banking and also develops its network. So as to establish digital transactions such as E-stalls and other so on. With a digital platfon, it can be fostered and given capital strengthening.

The synergy in building MSMEs should make a sustainable development model that needs to be patented and properly applied in our country. The enthusiasm to build MSMEs in whatever field they are involved in must be a necessity for the government in particular. Serious attention is a must. Fostering MSMEs must be a routine program that must be carried out every time. All strengths should be directed to build synergy between Indonesian MSMEs.

The enthusiasm to build innovative MSMEs is very important to prioritize. Where the desire to produce with a good level of innovation, will create new opportunities in competition. The element of innovation must be raised optimistically. Where we hope that the main spirit of MSMEs will appear by itself in every production process. (Apridar, Serambi Indonesia, 21 September 2020)

To be able to develop MSMEs, especially during the Covid pandemic, it is very necessary to use information and communication technology such as smartphones in running their business. Where with this technological equipment can facilitate and expand the business easily. Market control and information on prices that occur in various places can be monitored with this information technology equipment.

Based on Metadata, credit development towards MSMEs has increased from year to year. Where MSME credit is credit given to micro and medium enterprises in accordance with Law number 20 of 2008 concerning MSMEs. Adapu n the development of credit to MSMEs in 2018 as shown in table 3 below.

The growth of MSME credit every year has an impact on the growth of MSMEs itself. Where a lot of small and micro businesses, especially those that are very constrained by working capital, are helped by this policy. Policies that favor SMEs make informal activities, especially those in various rural areas, start to rise and develop. Unused land has been planted with various young plants that can be sold to the market. Thus, life in various parts of the village is getting more and more passionate.

Apart from working capital, MSMEs really need continuous guidance from local governments in particular, so that they can develop their businesses. Preparation of infrastructure for information technology is especially needed by MSMEs, so that they can take advantage of the network for digital transactions. 
TABLE 2.

UMKM CREDITS

\begin{tabular}{|l|l|r|}
\hline \multicolumn{1}{|c|}{ DATE } & \multicolumn{1}{c|}{ TITLE } & \multicolumn{1}{c|}{ HITS } \\
\hline $20-05-2019$ & MSME Credit Data September 2018 & 8151 \\
\hline $20-05-2019$ & MSME Credit Data for October 2018 & 466 \\
\hline $20-05-2019$ & November 2018 MSME Credit Data & 449 \\
\hline $20-05-2019$ & MSME Credit Data December 2018 & 3526 \\
\hline $14-12-2018$ & $\underline{\text { MSME Credit Data for August 2018 }}$ & 4373 \\
\hline $9 / 11 / 2018$ & $\underline{\text { MSME Credit Data July 2018 }}$ & 1689 \\
\hline $8 / 11 / 2018$ & $\underline{\text { MSME Credit Data June 2018 }}$ & 649 \\
\hline $8 / 11 / 2018$ & MSME Credit Data May 2018 & 541 \\
\hline $8 / 11 / 2018$ & April 2018 MSME Credit Data & 933 \\
\hline $8 / 11 / 2018$ & MSME Credit Data March 2018 & 1365 \\
\hline
\end{tabular}

Source: Metadata

MSMEs need continuous coaching so that they are able to compete with large companies that are already established from various sides. Especially for marketing, special guidance is needed so that MSMEs are able to expand their business. If the bigger market share is obtained by MSMEs, it will be easier to increase their business activities.

\section{CONCLUSIONS AND SUGGESTIONS}

Conclusion

1. Economic development model from which future outbreaks covid-19 is the economic development beroriantasi to SMEs by way of utilizing information and communication technologies for SMEs in the running activity of His attempt.

2. Ori e ntasi and economic development appropriate and effective in building the economy of Indonesia is the sectors that absorb a lot of labor ( $\mathrm{p}$ indigenous ka rya).

3. Empowerment of SMEs is very influential on the acceleration of the economic cycle so as to $\mathrm{m}$ eningkat $\mathrm{k}$ an economic growth. With the rise of MSMEs, economic inequality is also getting smaller because more than 90 percent of
Increasing the production of MSMEs which occurs gradually, will certainly make the people's economy grow by itself. Where UMKM is a community business sector which amounts to 90 percent more than the total entrepreneurs in the Republic of Indonesia. So that the government should pay more attention to MSMEs.

economic operators are included in the category of MSMEs.

Suggestions

1. It is time for the government to pay more attention and be willing to foster MSMEs, because the biggest contribution to economic growth and reducing economic inequality which is very significant is MSME. With the rise of MSMEs, the economy of the nation and the state arose.

2. The easing policy on banking and non-bank credit requirements for MSMEs needs to be maintained and enhanced.

3. The government needs to foster MSMEs, especially so that they are able to use information and communication technology to carry out their business.

\section{REFERENCES}

Abidin, M. (2015). Fiscal Policy and Increasing the Economic Role of MSMEs. Retrieved 
from https://www.kemenkeu.go.id/publikasi/artikeldan-opini/keb Policy-fiskal-dan-penlikasi-peranekonomi- umkm/

Aida, NR (2020, June 13). Corona Virus Update in the World: 214,894 Infected People, 83,313

Healed, 8,732 Died. Kompas.com . Downloaded from https://www.kompas.com/tren/read/2020/03/19/0816 33265/update-virus-corona-di- world-214894-peopleinfected-83313-cured-8732

Andi Amri , (2020) Impact Covid Against U-19 MKM In Indonesia, Journal of Brand, Volume 2 \# 1, June 2020

Arifin, D. (2020). Social Safety Network Reduces the Economic Impact of Communities Amid the COVID19 Pandemic. Retrieved from https://bnpb.go.id/berita/jaring-pengaman-socialkurangi-dampak-ekonomi-masyarakatdi-tengahpandemi-covid19

Apridar (2020), Time for High-tech MSMEs to Become Economic Locomotives, Serambi Indonesia, Monday, September 21, 2020.

Apridar, M. Rasyidin (2012) Economic Statistics, Publisher Unimal Press, Malikussaleh University, Lhokseumawe.

Apridar (2010), Economic Theory; History and Development, Publisher Graha Ilmu, Yogyakarta.

Apridar et al (2019) Convergence of Economic Growth; Post-Implementation Analysis of Regional Autonomy in Indonesia, Publisher Graha Ilmu Yogyakarta.

Bank Indonesia (2020), Credit Data for Micro, Small and Medium Enterprises (Metadata)

Baker, T., \& Judge, K. (2020). How to Help Small Businesses Survive COVID-19. Columbia Law and Economics Working Paper ( 620). Retrieved from http://dx.doi.org/10.2139/ssrn.3571460 BNPB. (2020). Covid-19 infographic. Retrieved from https://loker.bnpb.go.id/s/GugusTugasCovid19? path $=\% 2$ FInfogografi $\% 20$ Data

Burhan, F. (2020). Business Drops Due to Corona Pandemic, MSMEs Can Uabh Business Strategies. Retrieved from https://katadata.co.id/berita/2020/04/15/bisnisanjlok-akibat-pandemi-corona-umkm-bisa-ubahstrategi-usaha

Damanhuri Didin S92016) Main Material in the Field of Economic Studies, National Defense Institute of the Republic of Indonesia, Jakarta

Dana Riksa Buana (2020) Analysis of Indonesian Society Behavior in Facing the Corona Virus Pandemic (Covid-19) and Tips for Maintaining Mental Welfare, Mercubuana University.

Febrantara, D. (2020). How are SMEs in Various Countries Handling During the Covid-19 Pandemic? DDTC Fiscal Research. Retrieved from https://drive.google.com/drive/folders/1MY31I OC3gWq-EgzNkuJzqJnB9PV6qA2D

Gloria Setyvani Putri

", https://www.kompas.com/sains/read/2020/06/11/09 0200523/update-corona-dunia-11-juni-74-juta-orangterinf-379-juta-sembuh $?$ page $=$ all

Hadiwardoyo, W. (2020). National Economic Losses Due to the Covid-19 Pandemic. Journal of Business and Entrepreneurship, Vol. 2 No. 2 April 2020. doi: 10.24853 / baskara.2.2.83-92

Kemenkop-UKM. (2020). The Minister of Cooperatives and UKM Presents the KUKM Economic Recovery Scheme in the Period and Post COVID-19. Retrieved from http://www.depkop.go.id/read/menkop-danukm-paparkan-skema-pemulihan-ekonomi-kumkmdi-masa-dan-pasca-covid-19

Koesmawardhani, NW (2020, March 17). Government Sets Corona Disaster Emergency Period until May 29, 2020. Detiknews . Downloaded from https://news.detik.com/berita/d- 4942327 / government-set-the-emergency-disaster-corona-until29-mei-2020

Muhammad Ahsan Ridhoi, https://katadata.co.id/berita/2020/05/15/p Pre diction-pemulihan-ekonomi-pasca-corona-dari-kurvav-sampai-logo-nike

Maqdis ( 2017), Journal of Islamic Economic StudiesVolume 2, Number 2, July-December 2017 Center for Economic and Social Studies (CESS) and The Center for Micro and Small Enterprise Dynamic (CEMSED), SMEs in Indonesia are classified as

Prasetyo, A., \& Huda, M. (2019). Analysis of the Role of Small and Medium Enterprises on Labor Absorption in Kebumen Regency. Business Focus: Media Management and Accounting Studies, 18 (1), 26-35.

Sudaryono (2018), Research Methodology; Quantitative, Qualitative, and Mix Method, PT Rajagrafindo Persada, Jakarta.

Susilawati, S., Falefi, R., \& Purwoko, A. (2020). Impact of COVID-19's Pandemic on the Economy of Indonesia. Budapest International Research and Critics Institute (BIRCI-Journal): Humanities and Social Sciences, 3 (2), 1147-1156. unique. http://www.idwikipedia.org 